\title{
LEGAL STANDING OF PRE- CONTRACTUAL GOOD FAITH PRINCIPLE AS A LAW REFORMATION OF INDONESIAN CONTRACT LAW
}

\author{
N. Ike Kusmiati \\ Faculty of Law, Universitas Pasundan \\ E-mail: ike.kusmiati@unpas.ac.id
}

\begin{abstract}
Good faith plays an important role in a contract since it holds a dominant position either during pre-contractual phase or when a contract is executed. However, pre-contractual good faith in Indonesian Civil Code is not recognized as such there is no legal assurance. In fact in pre-contractual stage, the parties already put some investment based on trust and hope, however, they faced dead end and they did not reach an agreement. This was tinted with the fading of wall between two major legal systems: Common Law System and Civil Law System as a result of dynamic in business relation involving countries bringing some developments in contract law. The extension in the substance of good faith in Article 1338 verse (3) of the Civil Code should not be implemented so grammartically that good faith does not only appear during the execution of the contract but it should also be interpreted during the whole process of the contract that good faith should lay the foundation of the parties relation both in pre-contractual phase and during the contract such that the good faith in Article 1338 verse (3) of Civil Code functions dynamically. In UPICC, the provision of good faith is stipulated in Article 1, 7 stressing on the importance of good faith and fair dealing. This stressing underlays the process of contract agreement. Good faith should be interpreted and formulated during the whole process of contract. Under the traditional doctrine of Common law, court cannot punish the defendant because Common Law system does not recognize the good faith principle in negotiation process. Nevertheless, modern law contract waives the legal assurance to reach a substantial justice that good faith is not only applied in a contractual relation but also in a pre-contractual. Meaning, good faith does not only bind upon matters explicitly stated in the agreement, but also upon ones that traditionally are required by appropriateness, tradition, or the law as stipulated in Article 1339 of the Civil Code and Article 6:248 of Netherlands NBW. The good faith and fair dealing principles should be the underpinning of contract law. Each party should uphold the principles of good faith and fair dealing in the whole process of the contract starting from negotiation, contract arrangement, the execution of the contract as far as the termination of the contract particularly in the reformation of Indonesian future contract law.
\end{abstract}

Keywords: Legal standing, pre-contractual good faith, Indonesia

\section{A. INTRODUCTION}

The policy on national law reform should start from the Constitution by exerting all potentials and the power of our resources and predicting the condition affecting either on national, regional, or globar level. This policy requires direction in every measures taken for the development of the law to keep those law products formulated 
are in one system and at the same time to avoid overlapping and contradicting regulations and be misplaced in the international relations.

To encourage those aboves, future law reformation should focus on strategic measures that is inclusive to all elements of legal system i.e. legal substance, legal structure, and legal culture. The state law principle and other principles should act as the value orientation in every strategic measures of the law reform.

The main shortcoming of law often dealt with by business actors in Indonesia is legal uncertainty. Whereas the uncertainty of the law is necessary to estimate and to anticipate risk. For given country, legal assurance is even one of factors significant for the survival of one's economy.

For law to be able to play its role to provide legal assurance for the business actors, government is responsible to make the law dignified by responding to and following up the opinion and ideas of the contract law experts so the law is able to play its role to create a conducive climate for business to support the development of economy in Indonesia and to adapt with current development of contract law.

Significant pillar in the history of Indonesian contract law is the promulgation of contract law that adopts various important provisions nationally and internationally either those adopted by the United Nations Convention on International Sale of Good) or UNIDROIT (Principles of International Commercial Contract) that can conducively keep up with the development of today contract.

It is to fill the vacancy of contract law in Indonesia that is behind the countries ratifying the contract provisions in both CISG and UNIDROIT, in particular to fill the good faith principle in pre-contractual stage that has not yet stipulated since it is vital to protect the parties in the contract from damage. Often parties make transactions or legal actions during deliberation or negotiation because they put trust and relied reasonably that the contract will be well executed. In contrast, however, the agreement is not reached and generates damage for the other party.

Problems occur before the agreement is entered into, in the preliminary negotiation. One of the parties committed a legal action such as borrowing money, purchasing a piece of land, in fact it all was not agreed upon yet between parties about the business contract discussed. It was because one of the parties fully relied to the 
promises made by its business partner. When finally it faced dead end and agreement was not reached, they cannot be sued for all the investment made by the partner since the contract, under classic theory, was not entered into.

In reality, the understanding of good faith often overlapped with reasonableness and fairness (redeljkheid en billjkheid). Good faith contains appropriateness and vice versa. Therefore in court, good faith and appropriateness is understood as complementary principle. This writing aims to discuss about how important to stipulate good faith since either negotiation or pre-contractual phase in which one of the parties believes and rely that the agreement will start with honesty, openness to secure legal assurance. In reality, it aims reformation in future contract law as mandated in international contract law; both in CISG (United Nations Convention on Contractsfor the International Sale of good) and in UNIDROIT (Principles of International Commercial Contracts) that upholds good faith and fair dealing principles in the implementation of the contract since the negotiation process, contract making, implementation to the termination of contract $\mathrm{i}^{\mathrm{i}}$.

The development of international contract law generated by the interest of countries to implement commercial contract, it is certainly, for Indonesia, to harmonize its contract law with international laws applied as the principles of the basic contract.

In Indonesian Civil Law, the provision of good faith during pre-contractual stage is not recognized. It is only implicite. Good faith during pre-contractual stage is only interpreted dynamically from Article 1338 verse (3) of Civil Code that contract should be carried out with good faith to secure legal assurance between parties.

Accordingly, it is significant to stipulate good faith since pre-contractual stage to reform Indonesian contract law in the future. As in Netherlands, this point is regulated in Article 6:2 of NBW stipulating that parties should act in accordance with the provisions fairly because contract should lay above good faith and fair dealing.i

Indonesian Civil Code is vacant for this provision, particularly after electronic commerce was born. It cannot be reached with the provisions in the Civil Code while this practice cannot be held and is inevitable in commercial business among parties including in international commerce. 
Common Law countries such as United States of America applies doctrine of promissory estoppel in its courts as a means of protection for parties suffer injury due to trust and reasonables relied upon what is promised by the other party in precontractual stage.iii

Some judgments in Indonesian court did not consider good faith during negotiation because, under the classic theory, in the case the agreement is to fulfill certain requirements, the agreement does not exist and it is non-binding accordingly. Consequently, one that trusts the promises given by the other party is not protected and cannot file any charges against.

A note should be taken on that good faith is actually recognized more in Civil Law system rather that in its counterpart, Common Law system. Catherine Elliot and France Quinn argued that ${ }^{\text {iv }}$

For a term to be unfair, the 'significant imbalance' it generates musbe 'contrary to good faith'The concept of good faith is not one which is familiar to lawyers in England and Wales, but in the light of the law in other European countries it is likely to require that contracting parties deal with each orther in an open, honest way, taking into account their relative bargaining strengths

Referring to the modern theory, good faith that was more familiar in Civil Law is now starting to be common in Common Law that good faith means that it is not applied only during the execution but during the pre-contract as well, as it is stipulated in Article 1338 verse (3) of Civil Code. In this case, questions are raised about whether a legal relation occurs pre-contract or post-contract; what relation occurs pre-contract that a party, during negotiation, can ask for other's responsibility while they have not reached yet the final agreement to enter into the contract.

Legal standing of pre-contractual good faith in a contract is necessary to study to get in-depth understanding on how vital good faith is in pre-contractual stage or in negotiation between parties to ensure legal assurance.

\section{B. METHOD}

This research can be classified as research on the principles of law. In Soerjono Soekanto's opinion, a research on legal principle is conducted upon body of norms as 
a guidance of conduct and behavior. The research can be conducted upon primary and secondary law materials as long as they contain principles of law. Research on legal principles is a philosophical research because legal principle is the idea of law. ${ }^{\mathrm{v}}$

Peter Mahmud Marzuki argued that this research used conceptual approach. At this point, this research does not go away from the existing regulations related to the problems studied. In constructing the concept, what author firstly done was starting from the arguments and doctrines developed in the science of justice.

This research was a study on document using existing law materials including regulations as primary law materials and books as secondary law materials relevant to the problems studied, and judgment of the court used as supplementary materials to analyze.

\section{RESULT AND DISCUSSION}

The main weaknesses of law mostly encountered by business actors in Indonesia is this issue of legal uncertainty. Actually, legal uncertainty is necessary to estimate and to anticipate risk. Even for a country, legal assurance is one highly supporting factor for the economic power of a given country.

For law to play its role to provide legal assurance for the business actors, government is responsible to ensure the dignity of the law by responding and following up the ideas and opinions of the experts in contract law for law in the future can play the role to create a conducive climate for the business actor in supporting the development of economy in Indonesiavi and to adapt with current development of contract law.

Important pillar in the history of contract law in Indonesia is the promulgation of the contract law that can adopt significant provisions nationally and internationally. Both the provisions adopted by CISG (United Nations Conventions on International Sale of Good) and UNIDROIT (Principles of International Commercial Contract) that can keep up with current development of contract.

It is to fill the vacancy of contract law in Indonesia that is left behind countries ratifying contract provisions of both CISG and UNIDROIT especially vacancy regarding the provision of good faith in pre-contractual stage. Consequently, it is 
essential to protect parties in the agreement from harm. Often parties commit transactions or legal actions during agreement or negotiation because they trust and relied that the contract will executed well, however, most of the time agreement cannot be reached and damaging other party.

The role of the principle in all legal system is so vital in the case problems happen that legal principle is the basis or foundation supporting the holding of the contract. To understand the meaning of the legal principle, some doctrines set the definition as follows:

a. Bellefroid, that general legal principle is a basic norm derived from positive law of which is not regarded to be derived from more common rules. Accordingly, general principle is the crystallization of the positive law in a community.

b. Van Eikema Homes, that principle is not a concrete legal norm but is a general basis or guidance for applied laws. It is a foundation or direction in the construction of positive law.

c. Paul Scholten, that asas hukum is basic ideas inside and behind each legal system formulated in the regulations, laws, and decisions of court related to the stipulations and individual decisions that can be deemed as the elaboration.

One of the important principles is freedom of contract stipulated in Article 1338 verse (1) of the Civil Code which basically recognizes the freedom and independence of parties in entering into the contract. The freedom and independence of parties are no more than the realization of the upheld autonomy of parties.

The binding power of a contract existed a long with the principle of freedom of contract is the manifestation of human relation pattern reflecting the values of believes in the contract. Eggens argued that noble man will keep their promises while Grotius seeing the basis of the consensus in nature law that "promise is binding (pacta sunt servanda) because we have to keep our promise"vii 
The provision of good faith in Articlw 1338 verse (3) of Civil Code stating that an agreement should be executed under good faith. Meaning that the contract should be executed with appropriateness and justice. viii

The decision of Hoge Raad dated 9 February 1923 considered that "agreement should be executed", "volgens de eisen van redelijkheid en billijkheid" meaning that good faith should be performed with appropriateness and pertinence. P.I. Werry interpreted "redelijkheid en billijkheid" with "faith and appropriateness". Redelijk means rational, acceptable by reason, reasonable, while billijkheid means appropriate and just. Therefore, "redelijkheid en billijkheid " understood as all that can be felt and can be accepted by reason, fair, and just valued by written objective norms and are not derived from the subjectivity of the parties. ${ }^{\text {ix }}$

P.L. Werry argued that this norm, naturally, is the norm of appropriate care in the society". This doctrine elaborates that under the Article 1338 verse (3) of Civil Code, the conduct of the parties during the contract performance should be tested under written objective norms. These norms are objectives meaning that the conduct of parties should be with good faith not based on their own views, but under common perspective on this good faith. ${ }^{\mathrm{x}}$

J.M. van Dunne claimed that good faith (geode trouw; good faith) applies in the whole process of contract:

1. Pre-contractual phase

2. Contractual phase

3. Post contractual phase

Accordingly, Article 1338 verse (3) of Civil Code is so related to Article 1339 of the Code: "agreement is not binding to merely what explicitely written in it, but also to all, according to the nature of agreement, demanded by fairness, customary, or law. In this case, fairness is good faith. ${ }^{\mathrm{x}}$

Wirjono Prodjodikoro categorized good faith into two types: ${ }^{x i i}$

a. Good faith at the beginning of legal relation. In this phase, good faith normally is a prediction or one considers that the requirements necessary to commence a legal relation has already met. In this context, law provides protection to party with good faith, while the party with bad faith should be responsible and bear 
the risk. Good faith can be seen in Article 1977(1) and Article 1963 of the Civil Code stipulating one of the requirements to obtain ownership of goods through expiry. This type of good faith is subjective and static.

b. Good faith in the time of the performance of rights and obligations stated in the legal relation. The definition of this type of good faith as stipulated in Article 1338 (3) of the Civil Code is objective and dynamic according to the situation surrounding the relation.

The definition of good faith in Article 1338 (3) of the Civil Code means that the performance of the agreement with good fait is dynamic. It means that to perform the action, honesty should be running in the conscience of a man. Always remember that as a part of society, man should be away from harming other people, or from using words harshly when arranging an agreement. Both parties should consider these and not be allowed to use other people's negligence to gain advantage.

The understanding of the elements of good faith in Article 1338 verse (3) of the Civil Code should not be interpreted grammatically that good faith applied only when contract is performed. Good faith should lay in the entire process of contract that good faith should be the basis of parties' relation in the stage of pre-contract and contract performance. Therefore, its function as in Article 1338 verse (3) is dynamic, covering the whole process of contract. ${ }^{\text {xii }}$

The development of good faith principle post World War II plays significant role that limits, omits where good faith applies as general legal principle. P.L. Wery divided this development of good faith post WWII into 2:xiv

1. Limiting and Omitting

Hoge Raad as well as new BW allows the limitation of agreement at the point where the performance according to words is unacceptable for unfairness. It is understable because the function of limiting is an exception to the very vital principle: pacta sunt servanda. For law scholars, it is significant because, in fact, according to the Supreme Judge in Netherlands, the legal standing of good faith in unwritten law is higher than a binding written law. 
2. Good faith as general legal principle

Good faith in Article 1338 verse (3) of BW only applies during performance of contract, only in contractual relations. Post World War II, Hoge Raad extended the application of good faith to other legal fields. Certain legal relation that is not contractual is under good faith as well. Hoge Raad considered that good faith as general legal principle, underlaying entire legal relation.

a. Pre-contractual Legal Relation

When two parties negotiate to enter into an agreement, occurs among them, according to Hoge Raad, a special relation called pre-contractual under good faith principle. Hoge Raad decided that parties negotiating bear basic obligations based on good faith i.e. obligation to check and obligation to notify. For example, when negotiation on home purchase occurs, the buyer is in doubt if they are obliged to check if there is any official agendas such as to revoke ownership, and when the ownership was revoked, he cannot be sued for cancelling with the ground misleading. On the other hand, the seller is obliged to inform all what they understand and what is important and stating explicitely that there is no official agendas, the buyer does not have to check anymore. Judge should consider the obligation with each party based on the performance of good faith.

b. Legal relation among the heirs

Hoge Raad considered that in the case of division and separation of joint property, parties should act under good faith.

Article 1.7 and 2.15 of UPICC stress the necessary of good faith and fair dealing and forbid negotiation of contract with bad faith. Good faith should be interpreted and formulated in the entire process of contract. Therefore, in doing their activity, business actor should not harm other party and to not get advantage from other party's negligence. Contract is not determined by sentences formulated by other party, instead judge can interfere about the freedom of contract of parties by underpinning good faith principle. The content can be determined contradictory with those 
sentences. Accordingly, contract cannot be set merely by words formulated by the parties but also fairness and good faith. ${ }^{\mathrm{x}}$

In general, the chapter on UPICC contains good faith principle and honesty meaning that the principle is underpinning of the contract law. Each party should uphold principles of good faith and fair dealing in the entire contract performance since the negotiation process, contract performance, to the termination of contract.xvi

Therefore, good faith in pre-contract is important because trust has been established. The expectation that agreement the parties entered into will be performed well because good faith provide fairness to all parties without incurring harm to others, even though contract is not performed yet. Certainly, legal relation is already established between parties even though final agreement about the contract is yet to reach.

In countries applying Civil Law System such as France, Netherlands, and Germany, court applies good faith principle not only at the stage of contract signing and performing but aslo in the negotiation stage of contract therefore pre-contractual promises bear legal consequence and can be sued for remedy when the promises are denied. Countries applying Common Law system such as United States of America, protection is given to parties suffering damage due to trust and reasonable relied on promises given in pre-contractual stage.

\section{CONCLUSION}

Good faith should not only exist in the performance stage of contract but it should also underlay the pre-contractual phase because good faith should be reflected in the entire process of contract. Starting from negotiation process, contract making, contract performance including the termination of contract, they all should be closed under good faith.

The legal standing of pre-contractual good faith in Indonesian Civil Code is still weak. There is no provisions stipulating so it creates multi-interpretation, overlap that incurs fundamental problems even though in Article 1338 verse (3) of Civil Code stipulates the good faith in contract performance. Consequently, it creates legal uncertainty. Many cases occurred creates legal problems for parties who since the 
preliminary negotiation have committed legal action to secure the contract with trust and hope for the performance by other party. It create legal uncertainty between parties.

In Article 1.7 UPICC and NBW, it is described the stress on the necessary of good faith and fair dealing and forbid the process the contract negotiation with bad faith. It means that parties cannot harm other party and cannot take advantage from other people's negligence for their own benefit.

Therefore, the construction of pre-contractual good faith holds vital position in the effort of legal reformation of future Indonesian contract law for law to play role to ensure legal assurance of business actors so in the future contract law can function as a guide to create conducive climate for the business actors. 


\section{REFERENCES}

1. Adi Sulistiyono and Muhammad Rustamaji, Hukum Ekonomi sebagai panglima, Masmedia Buana Pustaka, Sidoarjo, 2009, p. 22

2. Agus Yudha Hernoko, Hukum Perjanjian Asas Proporsionalitas Dalam Kontrak Komersial, 2014.

3. Asosiasi Pengajar Hukum Keperdataan IV Proceeding, Mencari Model Pembaruan Hukum Perikatan Penormaan Prinsip-Prinsip dan langkah Legislasi, Inteligensia Media, Malang, 2018.

4. Hijma Jaap en Snijders Heng, The Nederlands New Covil Code (Kitab UndangUndang Hukum Perdata yang Baru), Grafika Desa Putera, Jakarta, 2010.

5. P.L.Werry, Perkembangan Hukum Tentang Itikad Baik Di Nederland, Percetakan Negara RI, Jakatra, 1990.

6. Soerjono Soekanto, Penelitian Hukum Normatif Suatu Tinjauan Singkat, Rajawali Pers, Jakarta, 1986.

7. Suharnoko, Hukum Perjanjian Teori dan Analisa Kasus, Prenada Media, Jakarta, 2004.

8. Taryana Soenandar, Prinsip-prinsip UNIDROIT Sebagai Sumber Hukum Kontrak dan Penyelesaian Sengketa Bisnis Internasional, Sinar Grafika, Jakarta, 2004.

iyana Soenandar, Prinsip-prinsip UNIDROIT Sebagai Sumber Hukum Kontrak dan Penyelesaian Sengketa Bisnis Internasional, Sinar Grafika, Jakarta, 2004, p. 43

ii Hijma Jaap en Snijders Heng, The Nederlands New Covil Code (Kitab Undang-Undang Hukum Perdata yang Baru), Grafika Desa Putera, Jakarta, 2010, pp. 12-13

iii Suharnoko, Hukum Perjanjian Teori dan Analisa Kasus, Prenada Media, Jakarta, 2004, p. 3 iv Asosiasi Pengajar Hukum Keperdataan IV Proceeding, Mencari Model Pembaruan Hukum Perikatan Penormaan Prinsip-Prinsip dan langkah Legislasi, Inteligensia Media, Malang, 2018, p. 274.

v Soerjono Soekanto, Penelitian Hukum Normatif Suatu Tinjauan Singkat, Rajawali Pers, Jakarta, 1986, p. 70.

vi Adi Sulistiyono dan ,Muhammad Rustamaji, Hukum Ekonomi sebagai panglima,

Masmedia Buana Pustaka, Sidoarjo, 2009, p. 22

vii Agus Yudha Hernoko, Op.cit, p. 128

viii Agus Yuda Hernoko, Ibid, p. 135.

ix Agus Yudha Hernoko, p. 136

xx P.L.Werry, Perkembangan Hukum Tentang Itikad Baik Di Nederland, Percetakan Negara RI, Jakatra, 1990, p. 9.

xi Agus Yudha Hernoko, Loc.cit, p. 136

xii Agus Yudha Hernoko, Ibid, p. 137.

xiii Agsu Yudha Hernoko, Ibid, p. 139 
International Journal of Science and Society, Vol 2, Issue 1, March 2020

xiv P.L. Wery. Loc.cit, p. 13

xv Agus Yudha Hernoko, Op.cit, hlm 143

xvi Taryana Sornandar, Op.cit, hlm 43 